\title{
A mathematical model in cellular manufacturing system considering subcontracting approach under constraints
}

\author{
Kamran Forghani, M.A. Sobhanallahi, A. Mirzazadeh ${ }^{*}$ and Mohammad Mohammadi
}

Department of Industrial Engineering, Faculty of Engineering, Kharazmi University, Karaj, Iran

\begin{tabular}{l}
\hline A R T I C L E I N F O \\
\hline Article history: \\
Received March 29, 2012 \\
Received in Revised form \\
June, 18, 2012 \\
Accepted 20 July 2012 \\
Available online \\
August 12012 \\
\hline Keywords: \\
University professor assessment \\
Self assessment \\
Assessment \\
University ranking
\end{tabular}
A B S T R A C T

\begin{abstract}
In this paper, a new mathematical model in cellular manufacturing systems (CMSs) has been presented. In order to increase the performance of manufacturing system, the production quantity of parts has been considered as a decision variable, i.e. each part can be produced and outsourced, simultaneously. This extension would be minimized the unused capacity of machines. The exceptional elements (EEs) are taken into account and would be totally outsourced to the external supplier in order to remove intercellular material handling cost. The problem has been formulated as a mixed-integer programming to minimize the sum of manufacturing variable costs under budget, machines capacity and demand constraints. Also, to evaluate advantages of the model, several illustrative numerical examples have been provided to compare the performance of the proposed model with the available classical approaches in the literature.
\end{abstract}

\section{Introduction}

The cellular manufacturing system (CMS) is a manufacturing application of the group technology (GT) philosophy (Schaller, 2007). In the CMS, parts with the similar production process are identified as parts families and each one is manufactured in a separate cell. The main purpose of CMS is to determine the parts families and machine cells under pre-defined objectives and constraints. The CMS has more advantages such as: decreased setup times, reduced work-in-process inventories, improved product quality, shorter lead times, reduced tool requirements, improved productivity, better quality and production control, increment in flexibility and decreased material handling cost (Solimanpur et al., 2009; Jeon \& Leep, 2006).

The issue of CMS has been widely investigated in the literature and it has received more attention by authors in the recent decades (see Singh (1993) for a literature review on CMS). There are literally 
various formulation and extensions on CMS in different environments to consider real-world situations.

In the uncertain demand conditions, Tavakkoli-Moghaddam et al. (2006) presented a new model for flexible inter and intra-cell layouts in CMSs with stochastic demands. Jeon and Leep (2006) developed a two-phase procedure to form manufacturing cells. The first phase is to identify part families based on a new similarity coefficient for two parts, which considers the number of alternative routes during machine failure. The second phase, considers the scheduling and operational aspects under demand changes for a given period to assign machines to part families. Schaller (2007) presented a model for cell formation with period-to-period demand variability and considers the size of the cell when determines the cost to process each part. This model also considers part reallocation or equipment reallocation among cells as the alternatives for the redesign of a CMS to handle longterm demand changes. Kia et al. (2011) presented a novel model for the layout design of dynamic cellular manufacturing systems (DCMS) under an uncertain environment, which incorporates several design features including intra-cell layout, operation sequence, operation time, alternative process routing, duplicate machines, machine capacity, route selection, production volume of parts and cell reconfiguration.

The cell formation (CF), one of the first and most important steps in designing CMSs, is to create completely independent machine cells and identify part families and allocate part families to the machine cells (Arıkan \& Güngör, 2009). In the literature of CF problem, some authors have taken into account exceptional elements (EEs) which are defined as machines required by two or more part families or conversely as parts that require processing on machines in two or more cells. By taking into account EEs, the material handling cost among cells take place and opens another research scope related to layout deign. For instance, Jolai et al. (2012) considered bi-objective cell formation and layout problems with different parameters such as: forward and backward transportation, number of EEs, different batch size for parts, different cell size and the sequence of operations. The layout of the system is obtained by locating the machines to the predefined linear positions. Chan et al. (2006) proposed a two-stage approach for solving machine-part grouping problem (MPGP) as well as cell layout problem (CLP). The first stage is to identify machine cells and part families and the second stage is to carry out a macro-approach to study the cell formation problem with consideration of machining sequence and minimizing intercellular movement as quadratic assignment problem (QAP). Also, Filho and Tiberti (2006) considered cell layout design with QAP to minimize volume of intercell moves and total within cell load variation. Chiang and Lee (2004) addressed the joint problem of manufacturing cell formation and its layout assignment to minimize the inter-cell flow cost under the cell size constraint, where machine cells are to be located along the popular bi-directional linear layout. They developed a simulated annealing approach augmented with dynamic programming algorithm, where the machine cells and their respective locations in the layout are simultaneously determined by dynamic programming.

Ghezavati and Saidi-Mehrabad (2011) attempted to assign a set of parts and machines to the cells by using queuing theory, to maximize average of the utilization factors for all machines (the probability of the busy machine). Solimanpur et al. (2004) addressed the scheduling of manufacturing cells in which parts may need to visit different cells. Panchalavarapu and Chankong (2005) incorporated assembly aspects associated with a product into the design of cellular manufacturing system. They proposed a mathematical model using similarity between part, machine and subassembly to determine assignment of parts, machines and subassemblies to manufacturing cells. Fallah-Alipour and Shamsi (2008) presented a new mathematical model to solve a cell formation problem based on sequence data in CMS, considering cell utilization levels. Kioon et al. (2009) proposed a comprehensive model in CMS, which integrates production planning, dynamic system reconfiguration, multiple routings and several other attributes. Heragu and Chen (1998) presented a model for CMS design, which incorporates three critical aspects including: resource utilization, alternate routings and practical 
constraints. Das et al. (2007) proposed a preventive maintenance (PM) planning model for the performance improvement of CMS in terms of machine reliability, and resource utilization. Sobhanallahi et al. (2002) discussed how a function is defined on similarity coefficients and generates a threshold value, which determines an upper band on the number of cells. They also presented a mathematical model for optimal production time in each cell. Table 1 shows a brief summary of the literature studies considering applied objectives and solution methods.

\section{Table 1}

A Summary of the literature studies

\begin{tabular}{|c|c|c|}
\hline Paper & Model type and objective function & Solution method \\
\hline Schaller (2007) & $\begin{array}{l}\text { Minimizing production cost of the parts }+ \text { total amortized cost of } \\
\text { machines }+ \text { cost of relocating machines into and out of cells } \\
\text { each period }\end{array}$ & $\begin{array}{l}\text { Heuristic algorithms and } \\
\text { TS }\end{array}$ \\
\hline Teymourian et al. (2011) & Minimizing costs of Intra-cell + Inter-cell + machine usage & ILOG/CPLEX \\
\hline Solimanpur et al. (2004) & Minimizing Intra-cell + Inter-cell costs & $\begin{array}{l}\text { A two-stage heuristic } \\
\text { named as SVS-algorithm }\end{array}$ \\
\hline Jeon \& Leep (2006) & $\begin{array}{l}\text { Minimizing inventory holding cost }+ \text { early/late finish penalty } \\
\text { cost }+ \text { operating cost }+ \text { machine investment cost }\end{array}$ & $\begin{array}{l}\text { GA and optimization } \\
\text { software (ILOG/CPLEX) }\end{array}$ \\
\hline $\begin{array}{l}\text { Tavakkoli-Moghaddam et } \\
\text { al. (2006) }\end{array}$ & Minimizing Intra-cell + Inter-cell costs & $\begin{array}{l}\text { Optimization software } \\
\text { (LINGO) }\end{array}$ \\
\hline Arıkan \& Güngör(2009) & $\begin{array}{l}\text { Fuzzy multi-objective parametric programming with: } \\
\text { minimizing cost of exceptional element elimination, minimizing } \\
\text { number of outer cell operations and maximizing of the utilized } \\
\text { machine capacity }\end{array}$ & $\begin{array}{l}\text { A two-phased solution } \\
\text { procedure }\end{array}$ \\
\hline Jolai et al. (2012) & $\begin{array}{l}\text { Bi-objective model with: Minimizing total material handling } \\
\text { cost and minimizing number of EEs }\end{array}$ & $\begin{array}{l}\text { Electromagnetism-like } \\
\text { algorithm }\end{array}$ \\
\hline Chan et al. (2006) & Minimizing total intercellular part distance movement. & GA \\
\hline Filho \& Tiberti(2006) & $\begin{array}{l}\text { Minimizing volume of inter cell moves }+ \text { total within cell load } \\
\text { variation }\end{array}$ & GA \\
\hline Chiang \& Lee (2004) & Minimizing inter-cell material flow cost & $\begin{array}{l}\text { Combination of SA, GA } \\
\text { and dynamic programming }\end{array}$ \\
\hline $\begin{array}{l}\text { Ghezavati \& Saidi- } \\
\text { Mehrabad(2011) }\end{array}$ & Maximizing utilization factor & $\begin{array}{l}\text { Combination of GA with } \\
\text { SA }\end{array}$ \\
\hline $\begin{array}{l}\text { Panchalavarapu \& } \\
\text { Chankong(2005) }\end{array}$ & Maximizing the sum of similarities & $\begin{array}{l}\text { A heuristic algorithm and } \\
\text { optimization software } \\
\text { (LINGO and } \\
\text { AMPL/CPLEX) }\end{array}$ \\
\hline $\begin{array}{l}\text { Fallah-Alipour \& Shamsi } \\
\text { (2008) }\end{array}$ & Minimizing Intra-cell + Inter-cell costs & $\begin{array}{l}\text { Optimization software } \\
\text { (LINGO) }\end{array}$ \\
\hline Kioon et al. (2009) & $\begin{array}{l}\text { Minimizing costs of machine relocation + machine maintenance } \\
\text { and overhead + machine operating + outsourcing + inventory } \\
\text { holding + internal part Production + inter-cell material handling } \\
+ \text { intra-cell material handling }\end{array}$ & ILOG/CPLEX \\
\hline Heragu \& Chen (1998) & $\begin{array}{l}\text { Minimizing costs of inter-cell movement }+ \text { cost of resource } \\
\text { under-utilization }\end{array}$ & $\begin{array}{l}\text { Benders' decomposition } \\
\text { approach }\end{array}$ \\
\hline Tsai et al. (1997) & $\begin{array}{l}\text { Minimizing cost of duplicating a machine }+ \text { inter-cell + } \\
\text { subcontracting }\end{array}$ & $\begin{array}{l}\text { Optimization software } \\
\text { (LINDO) }\end{array}$ \\
\hline Saad (2003) & $\begin{array}{l}\text { Multi objective goal programming model with acceptable level } \\
\text { of inter-cell movement, acceptable limit for tardiness, desired } \\
\text { level of system utilization and desired level of throughput }\end{array}$ & $\begin{array}{l}\text { Multiple objective tabu } \\
\text { search }\end{array}$ \\
\hline Car \& Mikac (2006) & Minimizing Intra-cell + Inter-cell costs & SA \\
\hline $\begin{array}{l}\text { Tavakoli-Moghadam et al. } \\
\text { (2007) }\end{array}$ & Minimizing total number of voids + total number of EEs & GA and Neural network \\
\hline Elbenani \& Ferland (2010) & Minimizing total number of voids + total number of EEs & ILOG/CPLEX \\
\hline Akturk \& Turkcan (2000) & $\begin{array}{l}\text { Maximizing difference between the revenue and the raw } \\
\text { material cost }+ \text { intra-cell material handling cost + variable } \\
\text { production costs + machine investment cost }\end{array}$ & $\begin{array}{l}\text { A heuristic local search } \\
\text { method }\end{array}$ \\
\hline
\end{tabular}


As mentioned earlier, EEs cause intercellular material flows, that is a major obstacle to reach the advantages of CMS such as reduction in set-up time, work-in-process inventory, material handling cost, improvement in material flow, space utilization, and etc. (Arıkan \& Güngör, 2009). However, without considering EEs, the utilization factor of machines and the total production volume would be decreased, because, the parts, which need to be processed in more than one cell cannot be produced. Therefore, to overcome this problem, this paper supposes that the production volume of each part is a continual decision variable and to satisfy demand of parts, each part can be produced and outsourced, simultaneously. Also, the EEs are totally outsourced; this assumption would increase the utilization factor of machines and also remove the intercellular material handling cost.

Jeon and Leep (2006) divided cell formation problem into three main categories:

a) Grouping part families or machine cells only

b) Forming part families and then machine cells

c) Forming part families and machine cells simultaneously

The part family grouping procedures are used for identifying groups of parts that are similar to each other. Some approaches focus only on the grouping machine cells and often assume that the part families already have been formed. The part-machine grouping procedures identify part families and machine groups sequentially or simultaneously. In this paper, decision about part families and machine cells have been made as a unique model and therefore, our problem fall into third category i.e. (c).

In this paper, a new model in cellular manufacturing systems (CMSs) has been addressed. In order to establish a high performance manufacturing system, it is assumed that subcontracting option is available, and unsatisfied demand of parts are outsourced under the extra costs i.e. the production volume of each part is a decision variable and each part can be produced and outsourced simultaneously (this extension causes that, unused capacity of machines can be minimized). In addition, in order to remove intercellular material handling cost, it is assumed that EEs are totally outsourced to the external supplier. The problem is formulated as a mixed-integer nonlinear programming considering machines capacity, budget and demand constraints to minimize variable cost during manufacturing. Since the proposed model is nonlinear, some methods have been applied to linearize it. Finally, CPLEX.10 is implemented to compare the proposed model against the classical CMS model in the literature through several numerical examples.

The reminder of this paper is organized as follows: In part (2), we give assumption and formulate proposed problem as a non-linear mixed integer programming. Part (3) is followed by some methods to linearize and simplify the model in order to solve it optimally. In part (4), the classical CMS has been defined and also several numerical examples have been involved in order to compare the developed model with the classical one. Finally part (5) includes our conclusions.

\section{Model formulation}

In order to remove intercellular material handling cost, we have assumed that each part is processed only in one cell and EEs are totally outsourced. In addition, to increase the utilization factor of machines, the production volume of each part is considered as a continual decision variable. Moreover, to satisfy part demands, the subcontracting option is available. It means that unsatisfied demand of parts is outsourced under the extra costs. This approach is clearly illustrated in Fig. 1(2). Consider a main product consists of 5 parts where parts 1, 2 and 3 are simultaneously produced and outsourced, and parts 4 and 5 as the EEs are totally outsourced. Furthermore, considering the real world's situation, it is supposed that each machine can contain more than one type; each type can 
change to the other types operation and has the specific production rate and purchase price. For example, in Fig. 1, L2 and L3 belong to the same machine family, but, differ together in type.

\subsection{Model assumptions}

Generally, the assumptions of this paper are as follows:

- The production volume of each part is a decision variable.

- Each part can be produced and outsourced, simultaneously.

- In order to remove inter-cell handling cost, each part is processed only in one cell and EEs are totally outsourced.

- Both the maximum number of cells and the capacity of cells to place machines are predetermined.

- Parts demand are deterministic.

- Each machine can contain several types.

- Number of each machine in each cell is considered as a integer decision variable.

- The production capacity of machines is limited.

- The budget for purchasing machines and constructing cells is limited.

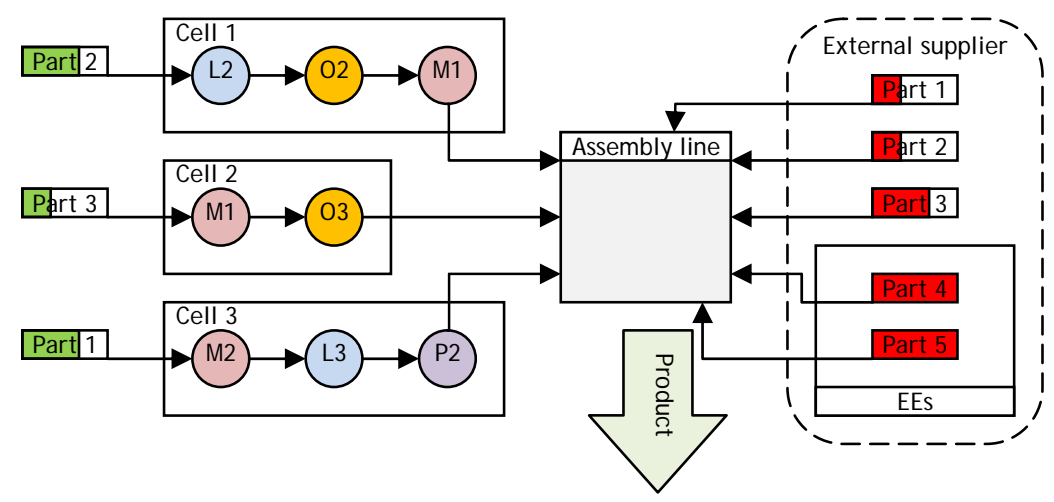

Fig. 1. The proposed production system considering subcontracting approach

\subsection{Notations}

The following notations and decision variables are applied in this paper:

c maximum number of cells permitted

$m \quad$ number of machines

$n \quad$ number of parts

$t_{k} \quad$ Number of type $k$ machines $k=1, \ldots, m$

$u_{k l} \quad$ capacity of machine $k$ type $l, k=1, \ldots, m, l=1, \ldots, t_{k}$

$c_{k l}^{m} \quad$ purchase price of machine $k$ type $l, k=1, \ldots, m, l=1, \ldots, t_{k}$

$c_{j}^{c} \quad$ formation cost of cell $j, j=1, \ldots, c$

$c_{i}^{p} \quad$ unit production cost of part $i, i=1, \ldots, n$ 
$c_{i}^{b} \quad$ unit outsourcing cost of part $i, i=1, \ldots, n$

$\mathrm{Ca}_{j} \quad$ capacity of cell $j, j=1, \ldots, c$

$d_{i} \quad$ demand of part $i, i=1, \ldots, n$

$a_{i k} \quad$ standard processing time of partion machine $k, i=1, \ldots, n, k=1, \ldots, m$

$B \quad$ total available budget

$M \quad$ A large enough number

\subsection{Decision variables}

$x_{i j} \quad 1$ if part $i$ is assigned to cell $j$; 0 otherwise

$z_{j} \quad 1$ if cell $j$ is formed; 0 otherwise

$y_{j k l} \quad$ number of machine $k$ typelis assigned to cell $j$

$p_{i} \quad$ Production quantity of part $i$

\subsection{The mathematical model}

The mixed-integer nonlinear mathematical model for the extended CMS $\left(\mathrm{CMS}^{\mathrm{E}}\right)$ problem is as follows:

$\mathrm{CMS}^{\mathrm{E}}: \operatorname{Min} \mathrm{TC}=\sum_{i=1}^{n}\left(\left(c_{i}^{p}-c_{i}^{b}\right) p_{i} \sum_{j=1}^{c} x_{i j}+c_{i}^{b} \cdot d_{i}\right)$

Subject to:

$\sum_{j=1}^{c} x_{i j} \leq 1, \quad i=1, \ldots, n$

$\sum_{k=1}^{m} \sum_{l=1}^{t_{k}} y_{j k l} \leq C a_{j}, \quad j=1, \ldots, c$

$z_{j}=\max _{i=1, \ldots, n}\left\{x_{i j}\right\}, \quad j=1, \ldots, c$

$\sum_{i=1}^{n} a_{i k} \cdot p_{i} \cdot x_{i j}-\sum_{l=1}^{t_{k}} y_{j k l} \cdot u_{k l} \leq 0, \quad j=1, \ldots, c, \quad k=1, \ldots, m$

$\sum_{j=1}^{c} \sum_{k=1}^{m} \sum_{l=1}^{t_{j}} c_{k l}^{m} \cdot y_{j k l}+\sum_{j=1}^{c} z_{j} \cdot c_{j}^{c} \leq B$ 
$p_{i} \leq d_{i}, \quad i=1, \ldots, n$

$x_{i j}=0,1, \quad i=1, \ldots, n, \quad j=1, \ldots, c$

$z_{j}=0,1, \quad j=1, \ldots, c$

$y_{j k l}=$ integer $, \quad j=1, \ldots, c, \quad k=1, \ldots, m, \quad l=1, \ldots, t_{k}$

$p_{i} \geq 0, \quad i=1, \ldots, n$

Objective (1) minimizes the total variable cost of manufacturing, including production and outsourcing costs. Constraint (2) ensures that each part is assigned only to one cell. Constraint (3) imposes the maximum number of machines allowed in each cell. Constraint (4) represents that the cell must be formed, if at least one part be assigned to it. Constraint (5) restricts that the capacity of machines of the same type in each cell is not violated. Constraint (6) ensures the budget limitation of machines procurement and cell formation costs. Constraint (7) is the parts demands constraint and finally set of constraints (8)-(11) are the logical binary, integer and non-negativity requirements on the decision variables.

\section{Model simplification and linearization}

Objective function (1) and constraint (6) are nonlinear due to presence of the product term. These terms can be linearized by adding a new positive variable, which is nominated as $\varphi_{i j}$ (where $\varphi_{i j}=$ $p_{i} \cdot x_{i j}$ ) and a set of constraints to the model. After replacing $p_{i} \cdot x_{i j}$ with $\varphi_{i j}$ and removing constant terms i.e. $c_{i}^{b} . d_{i}$ from objective function (1), the model is expressed as follows:

$\min T C \approx \operatorname{Min} \sum_{i=1}^{n}\left(\left(c_{i}^{p}-c_{i}^{b}\right) \sum_{j=1}^{c} p_{i} \cdot x_{i j}\right)=\sum_{i=1}^{n}\left(\left(c_{i}^{p}-c_{i}^{b}\right) \sum_{j=1}^{c} \varphi_{i j}\right)$

subject to: (1.2)-(1.4) and (1.6)-(1.11)

$\varphi_{i j} \leq p_{i}, \quad i=1, \ldots, n, \quad j=1, \ldots, c$

$\varphi_{i j} \leq M \cdot x_{i j}, \quad i=1, \ldots, n, \quad j=1, \ldots, c$

$\sum_{i=1}^{n} a_{i k} \cdot \varphi_{i j}-\sum_{l=1}^{t_{k}} y_{j k l} . u_{k l} \leq 0, \quad j=1, \ldots, c, \quad k=1, \ldots, m$

$\varphi_{i j} \geq 0, \quad i=1, \ldots, n$

In constraint (13), if $x_{i j}=1$, then $\varphi_{i j} \leq p_{i}$, and since the objective function minimizes negative coefficient of $\varphi_{i j}$ (Since $c_{i}^{p} \leq c_{i}^{b}$ ) therefore $\varphi_{i j}=p_{i}$; also if $x_{i j}=0$, then $\varphi_{i j}=0$. On the other side, we know that $p_{i} \leq d_{i}$ (see constraint (7)) and therefore, it is concluded that $\varphi_{i j} \leq d_{i}$. Finally, since each part is processed in one cell, i.e., $\sum_{j=1}^{c} x_{i j} \leq 1$, so $p_{i}$ is removed from the model and constraints (13), (7) and (14) are merged to the following constraint:

$\varphi_{i j} \leq d_{i} \cdot x_{i j}, \quad i=1, \ldots, n, \quad j=1, \ldots, c$ 
In addition, the maximum operator in constraint (4) is linearized as follows:

$z_{j} \geq x_{i j}$ and $x_{i j}=0 \& 1, \quad i=1, \ldots, n, \quad j=1, \ldots, c$

and since $0 \leq \frac{1}{n} \sum_{i=1}^{n} x_{i j} \leq 1$, therefore constraint (18) is reduced to the below constraint:

$z_{j} \geq \frac{1}{n} \sum_{i=1}^{n} x_{i j}, \quad j=1, \ldots, c$

Finally, the model of $\mathrm{CMS}^{\mathrm{E}}$ is expressed as the following mixed-integer programming (MIP) model:

$C M S^{E}: \operatorname{Min} T C=\sum_{i=1}^{n}\left(\left(c_{i}^{p}-c_{i}^{b}\right) \sum_{j=1}^{c} \varphi_{i j}\right)$

subject to:

$\sum_{j=1}^{c} x_{i j} \leq 1, \quad i=1, \ldots, n$

$\sum_{k=1}^{m} \sum_{l=1}^{t_{k}} y_{j k l} \leq C a_{j}, \quad j=1, \ldots, c$

$\sum_{i=1}^{n} a_{i k} \cdot \varphi_{i j}-\sum_{l=1}^{t_{k}} y_{j k l} \cdot u_{k l} \leq 0, \quad j=1, \ldots, c, \quad k=1, \ldots, m$

$\sum_{j=1}^{c} \sum_{k=1}^{m} \sum_{l=1}^{t_{j}} c_{k l}^{m} \cdot y_{j k l}+\sum_{j=1}^{c} z_{j} \cdot c_{j}^{c} \leq B$

$z_{j} \geq \frac{1}{n} \sum_{i=1}^{n} x_{i j}, \quad j=1, \ldots, c$

$\varphi_{i j} \leq d_{i} . x_{i j}, \quad i=1, \ldots, n, \quad j=1, \ldots, c$

$x_{i j}=0,1, \quad i=1, \ldots, n, \quad j=1, \ldots, c$

$z_{j}=0,1, \quad j=1, \ldots, c$

$y_{j k l}=$ integer $, \quad j=1, \ldots, c, \quad k=1, \ldots, m, \quad l=1, \ldots, t_{k}$

$\varphi_{i j} \geq 0, \quad i=1, \ldots, n$

\section{Comparison of the models}

In this section, the model of the $\mathrm{CMS}^{\mathrm{E}}$ is compared against the classical CMS model $\left(\mathrm{CMS}^{\mathrm{C}}\right)$ through several illustrative numerical examples. It is necessary to define the classical CMS problem before numerical example. 


\subsection{Classical CMS model}

As it was mentioned previously, we assumed that the EEs are totally outsourced to the external supplier and the remaining parts are simultaneously produced and outsourced in order to remove intercellular material handling cost. On the other hand, in the $\mathrm{CMS}^{\mathrm{C}}$ it is assumed that each part is processed in one cell or outsourced totally considering machine capacity (Schaller, 2007; Jeon \& Leep, 2006; Ghezavati \& Saidi-Mehrabad, 2011). This approach is clearly illustrated in Fig. 2. In this shape Parts 4, 3 and 1 are totally produced in Cells 1, 2 and 3 respectively, and parts 2, 5 and 6 are EEs, which are totally outsourced.

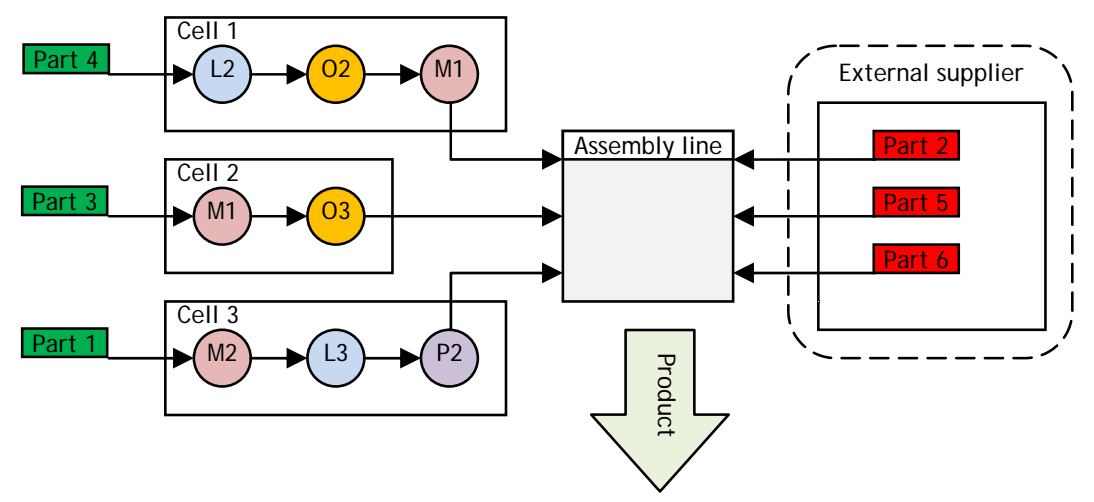

Fig. 2. The production system, representing $\mathrm{CMS}^{\mathrm{C}}$

In order to compare the $\mathrm{CMS}^{\mathrm{E}}$ and $\mathrm{CMS}^{\mathrm{C}}$, it is necessary to formulate $\mathrm{CMS}^{\mathrm{C}}$ as the presented framework of this paper. The MIP model corresponds to $\mathrm{CMS}^{\mathrm{C}}$ is as follows:

$C M S^{C}: \operatorname{Min} T C=\sum_{i=1}^{n} d_{i}\left(c_{i}^{p}-c_{i}^{b}\right) \sum_{j=1}^{c} x_{i j}$

Subject to: (21), (23), (25), (26) and (28)-(30)

$\sum_{i=1}^{n} a_{i k} \cdot d_{i} \cdot x_{i j}-\sum_{l=1}^{t_{k}} y_{j k l} \cdot u_{k l} \leq 0, \quad j=1, \ldots, c, \quad k=1, \ldots, m$

Objective function (31) minimizes the variable cost of manufacturing, including production or outsourcing costs and constraint (32) restricts that the capacity of each machine type in each cell is not violated. All remaining constraints are the same before explained.

\subsection{Numerical example}

In this section in order to compare the $\mathrm{CMS}^{\mathrm{E}}$ and $\mathrm{CMS}^{\mathrm{C}}$, three illustrative numerical examples (two from the literature) have been provided. These examples are studied with different parameters, including available budget, maximum number of cells and capacity of cells. All numerical instances are solved with CPLEX.10 on a PC with $2.4 \mathrm{GHz}$ CPU and 2 GB RAM.

In example.1, 10 parts should be produced or outsourced using 11 machines through 4 candidate cells. It is assumed that $C a_{j}=7$ and $c_{j}^{c}=800 \forall j$, and also each machine has one type (i.e. $t_{k}=1$, $\forall k$ ). The other necessary information has been illustrated in Table 2 . 
Table 2

The data set of example.1

\begin{tabular}{ccccccccccccc}
\hline M/P & P1 & P2 & P3 & P4 & P5 & P6 & P7 & P8 & P9 & P10 & $u_{k 1}$ & $c_{k 1}^{m}$ \\
\hline M1 & 0.0 & 0.0 & 1.4 & 0.0 & 0.0 & 0.0 & 1.3 & 0.0 & 0.0 & 1.7 & 30 & 45 \\
M2 & 0.0 & 0.0 & 0.0 & 0.0 & 0.0 & 0.0 & 0.0 & 0.0 & 0.9 & 0.6 & 25 & 380 \\
M3 & 0.0 & 1.0 & 0.0 & 0.0 & 1.8 & 0.0 & 0.0 & 0.0 & 1.2 & 0.0 & 20 & 210 \\
M4 & 1.6 & 0.0 & 0.0 & 1.4 & 0.0 & 0.0 & 0.0 & 0.9 & 1.7 & 0.0 & 18 & 100 \\
M5 & 0.0 & 0.0 & 0.0 & 0.0 & 0.0 & 0.0 & 0.0 & 1.8 & 0.0 & 0.0 & 30 & 230 \\
M6 & 0.0 & 0.0 & 0.8 & 0.0 & 1.0 & 1.9 & 0.0 & 1.6 & 0.0 & 1.4 & 32 & 150 \\
M7 & 1.1 & 0.0 & 0.0 & 0.0 & 0.0 & 0.0 & 0.0 & 0.0 & 0.0 & 0.0 & 15 & 160 \\
M8 & 0.0 & 0.0 & 0.0 & 0.0 & 1.1 & 0.6 & 0.8 & 0.0 & 0.0 & 0.0 & 16 & 145 \\
M9 & 0.0 & 0.7 & 0.0 & 0.0 & 0.0 & 0.0 & 1.8 & 1.5 & 1.0 & 0.0 & 25 & 140 \\
M10 & 0.0 & 0.0 & 2.0 & 0.5 & 0.0 & 0.0 & 0.0 & 0.0 & 0.0 & 0.0 & 20 & 30 \\
M11 & 0.0 & 0.0 & 0.0 & 0.0 & 0.0 & 1.8 & 0.0 & 0.0 & 0.0 & 0.0 & 15 & 80 \\
\hline$d_{i}$ & 20 & 35 & 26 & 32 & 26 & 28 & 16 & 17 & 20 & 10 & & \\
$c_{i}^{p}$ & 10 & 15 & 13 & 14 & 12 & 8 & 19 & 15 & 8 & 17 & 22 \\
$c_{i}^{b}$ & 15 & 20 & 16 & 18 & 17 & 12 & 23 & 20 & 13 & 2
\end{tabular}

Example.1 was solved with different available budgets and the results have been summarized in Table 3.The computational results revealed that the objective value of the $\mathrm{CMS}^{\mathrm{E}}$ is better than or equal to that of the $\mathrm{CMS}^{\mathrm{C}}$ (see Fig. 3 for differences among them) with an average gap of 7.99\%. In addition, in some cases the $\mathrm{CMS}^{\mathrm{E}}$ is better than $\mathrm{CMS}^{\mathrm{C}}$ both in objective and remaining budget.

Table 3

The computational results of example.1 considering different available budget

$\begin{array}{cccc}\mathrm{B} & \mathrm{CMS}^{\mathrm{E}} & \mathrm{CMS}^{\mathrm{C}} & \text { TC Improvement \% }\end{array}$
TC $^{*} \quad$ Remaining budget $\quad$ CPU time (s) TC $^{*} \quad$ Remaining budget CPU time

\begin{tabular}{cccccccc}
\multicolumn{1}{c}{$(\mathrm{s})$} & \\
\hline 1000 & -128.00 & 10 & 0.107 & -128 & 10 & 0.053 & $0 \%$ \\
1500 & -303.00 & 50 & 0.091 & -303 & 50 & 0.071 & $0 \%$ \\
2000 & -303.00 & 550 & 0.138 & -303 & 550 & 0.118 & $0 \%$ \\
2500 & -371.18 & 70 & 0.486 & -303 & 1050 & 0.145 & $18.37 \%$ \\
3000 & -458.56 & 60 & 0.336 & -403 & 390 & 0.154 & $12.12 \%$ \\
3500 & -472.62 & 370 & 1.447 & -453 & 315 & 0.146 & $4.15 \%$ \\
4000 & -518.56 & 5 & 2.736 & -481 & 260 & 0.220 & $7.24 \%$ \\
4500 & -584.40 & 70 & 15.962 & -533 & 20 & 0.223 & $8.80 \%$ \\
5000 & -623.12 & 25 & 90.058 & -553 & 35 & 0.221 & $11.25 \%$ \\
\hline 5500 & -629.84 & 480 & 501.491 & -583 & 445 & 0.199 & $7.44 \%$ \\
6000 & -696.58 & 5 & 241.958 & -611 & 390 & 0.283 & $12.29 \%$ \\
\hline 6500 & -741.12 & 15 & 1131.712 & -661 & 315 & 0.149 & $10.81 \%$ \\
7000 & -756.46 & 260 & 809.949 & -683 & 165 & 0.167 & $9.71 \%$ \\
7500 & -756.46 & 760 & 596.608 & -683 & 665 & 0.087 & $9.71 \%$ \\
\hline
\end{tabular}

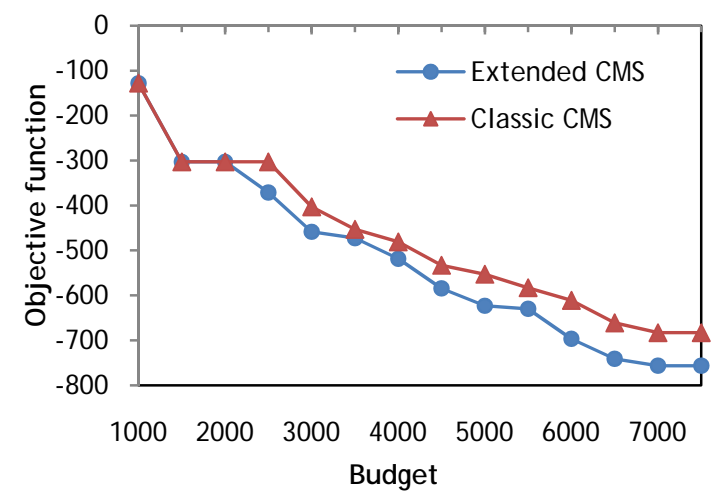

Fig. 3. Objective values of the $\mathrm{CMS}^{\mathrm{E}}$ and $\mathrm{CMS}^{\mathrm{C}}$ (example.1) 
Fig. 4 illustrates the specified machine cells and part families in example. 1 considering $B=7500$. This shape shows that 4 machine cells have been formed. Parts 3 and 6 have been recognized as the EEs and are totally outsourced to external supplier. In addition, parts 1, 2 and 10 are totally produced by the manufacturing system and remaining parts are simultaneously produced and outsourced.
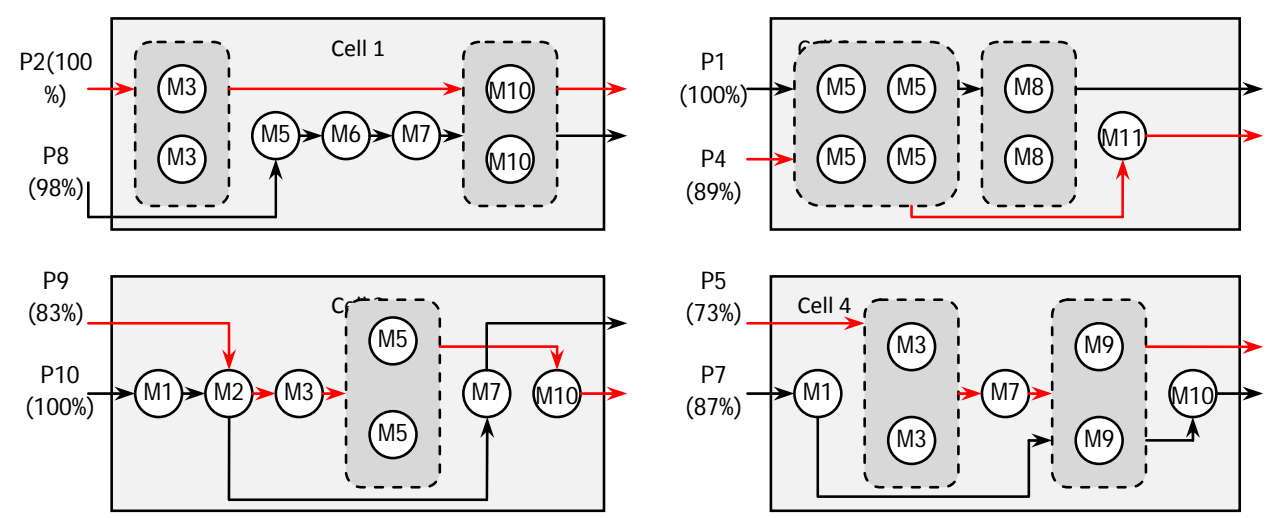

Fig. 4. Formed machine cells and part families in $\mathrm{CMS}^{\mathrm{E}}$ considering $\mathrm{B}=7500$ (example.1)

The next problem (example 2) has been selected from Arıkan and Güngör (2009), this example contains 10 parts and 9 machines and each machine has two types, the data set has been given in Table 4, also it is assumed that $c_{j}^{c}=100000 \forall j$, and $B=1000000$.

\section{Table 4}

The data set of example.2 (Arlkan \& Güngör, 2009)

\begin{tabular}{|c|c|c|c|c|c|c|c|c|c|c|c|c|c|c|}
\hline $\mathbf{M} / \mathbf{P}$ & 1 & 2 & 3 & 4 & 5 & 6 & 7 & 8 & 9 & 10 & $c_{k 1}^{m}$ & $c_{k 2}^{m}$ & $u_{k 1}$ & $u_{k 2}$ \\
\hline 1 & 3.0 & 0.0 & 2.2 & 0.0 & 0.0 & 0.0 & 0.0 & 0.0 & 0.0 & 4.6 & 45000 & 50784 & 140000 & 160000 \\
\hline 2 & 2.8 & 5.2 & 1.9 & 3.9 & 0.0 & 5.1 & 0.0 & 0.0 & 0.0 & 0.0 & 60000 & 67053 & 140000 & 160000 \\
\hline 3 & 5.5 & 4.3 & 0.0 & 0.0 & 0.0 & 0.0 & 0.0 & 0.0 & 0.0 & 0.0 & 37000 & 43944 & 140000 & 160000 \\
\hline 4 & 2.9 & 0.0 & 0.0 & 2.0 & 2.6 & 4.0 & 0.0 & 2.7 & 0.0 & 0.0 & 61000 & 67345 & 140000 & 160000 \\
\hline 5 & 0.0 & 0.0 & 0.0 & 4.3 & 0.0 & 4.5 & 0.0 & 0.0 & 0.0 & 0.0 & 35000 & 42414 & 140000 & 160000 \\
\hline 6 & 1.9 & 0.0 & 0.0 & 0.0 & 0.0 & 0.0 & 2.2 & 0.0 & 5.5 & 0.0 & 70000 & 75225 & 140000 & 160000 \\
\hline 7 & 0.0 & 0.0 & 0.0 & 0.0 & 3.4 & 0.0 & 1.2 & 4.7 & 0.0 & 2.5 & 50000 & 52741 & 140000 & 160000 \\
\hline 8 & 0.0 & 5.3 & 0.0 & 0.0 & 0.0 & 0.0 & 0.0 & 3.8 & 3.9 & 0.0 & 59000 & 63523 & 140000 & 160000 \\
\hline 9 & 0.0 & 0.0 & 0.0 & 0.0 & 0.0 & 0.0 & 4.0 & 0.0 & 0.0 & 1.8 & 49000 & 50632 & 140000 & 160000 \\
\hline$d_{i}$ & 33000 & 30000 & 20000 & 11000 & 18000 & 17000 & 46000 & 46000 & 16000 & 23000 & & & & \\
\hline$c_{i}^{p}$ & 3.8 & 4.0 & 3.0 & 4.0 & 4.5 & 3.0 & 4.2 & 4.3 & 4.6 & 4.0 & & & & \\
\hline$c_{i}^{b}$ & 4.2 & 4.3 & 3.5 & 4.4 & 5 & 3.9 & 4.4 & 4.6 & 5 & 5 & & & & \\
\hline
\end{tabular}

Example 2 was solved for different capacity of cells i.e. $C a_{j}=3, \ldots, 8 \forall j$. The results have been reported in Table 5.

\section{Table 5}

Computational results of example. 2 considering different cell capacity

\begin{tabular}{ccccccc}
\hline $\mathrm{Ca}_{j}$ & \multicolumn{3}{c}{ CMS $^{E}$} & \multicolumn{2}{c}{ CMS $^{C}$} & TC improvement \% \\
\cline { 2 - 5 } & TC & Opt. gap\% & CPU time $(\mathrm{s})$ & TC & CPU time (s) & \\
\hline 3 & -68006.38 & $0 \%$ & 9991 & -61700 & 27 & $9.27 \%$ \\
4 & -79556.90 & $5.32 \%$ & $10800^{*}$ & -70900 & 21 & $10.88 \%$ \\
5 & -81327.44 & $6.93 \%$ & $10800^{*}$ & -75500 & 2586 & $7.17 \%$ \\
6 & -82757.83 & $5.79 \%$ & $10800^{*}$ & -77500 & 14 & $6.35 \%$ \\
7 & -93371.63 & $0 \%$ & 364 & -81900 & 8 & $12.29 \%$ \\
8 & -93371.63 & $0 \%$ & 4139 & -84700 & 2 & $9.29 \%$ \\
\hline
\end{tabular}

\footnotetext{
* in this case the solver was interrupted after 10800 seconds (3 hours)
} 
The model of $C M S^{E}$ was optimally solved for $C a_{j}=3,7,8 \forall j$, but for $C a_{j}=4,5,6 \forall j$ the solver was interrupted after 3 hours. Fortunately, all cases in $\mathrm{CMS}^{\mathrm{E}}$ were solved with good optimality gap percent and the worst optimality gap percent was $6.93 \%$, from the other side the model of $\mathrm{CMS}^{\mathrm{C}}$ was optimally solved for all cases. The results show that in all cases the $\mathrm{CMS}^{\mathrm{E}}$ is considerably better than the $\mathrm{CMS}^{\mathrm{C}}$ with an average improvement percent of 9.21\%. Fig. 5 illustrates the differences between the $\mathrm{CMS}^{\mathrm{E}}$ and $\mathrm{CMS}^{\mathrm{C}}$ with respect to different cell capacity.

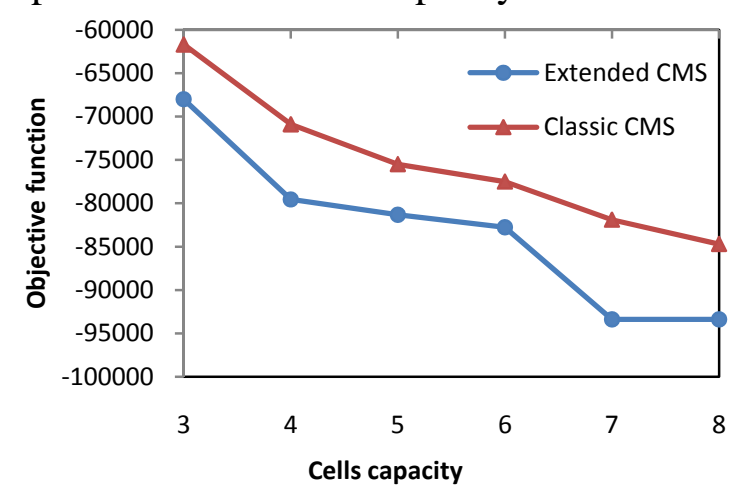

Fig. 5. Objective values of the $\mathrm{CMS}^{\mathrm{E}}$ and $\mathrm{CMS}^{\mathrm{C}}$ (example 2)

In addition, Table 6 shows the formed machine cells and parts families for example 2 considering $C a_{j}=5 \forall j$. In this case three cells have been formed, also parts 3, 5, 6, 8, 9 and 10 are totally produced by the manufacturing system and parts 4,2 and 7 are simultaneously produced and outsourced, furthermore part 1 has been recognized as the EE and completely is outsourced.

\section{Table 6}

Result of cell formation and parts families for example.2 considering $\boldsymbol{C} \boldsymbol{a}_{\boldsymbol{j}}=\mathbf{5}$

\begin{tabular}{ccc}
\hline Cell no. & Machines-type (number allocated) & Parts (production percent) \\
\hline 1 & M1-1(1), M2-2 (1), M4-1 (1), M5-1 (1), M7-1 (1) & P3 (100\%), P4(82.28\%), P5(100\%), P6(100\%) \\
2 & M2-1(1),M3-1(1),M8-2(1) & P2(89.74\%) \\
3 & M1-1(1), M6-2(1), M7-1(1), M8-1(1), M9-2(1) & P7(64.46\%), P8(100\%), P9(100\%), P10(100\%) \\
\hline
\end{tabular}

The last problem (Example 3) has been selected from Venugopal and Narendran (1992). There are 15 machines and 30 parts, the data set representing the machine-part matrix as well as demand of parts has been included in Table 7, the remaining parameters are generated randomly and have been given in Table 8 and Table 9. In this example we have assumed that each machine has three types (i.e. $t_{k}=3, \forall k$ ), also $c_{j}^{c}=1000, \forall j$.

\section{Table 7}

Machine-part matrix related to example.3 (Venugopal \& Narendran, 1992)

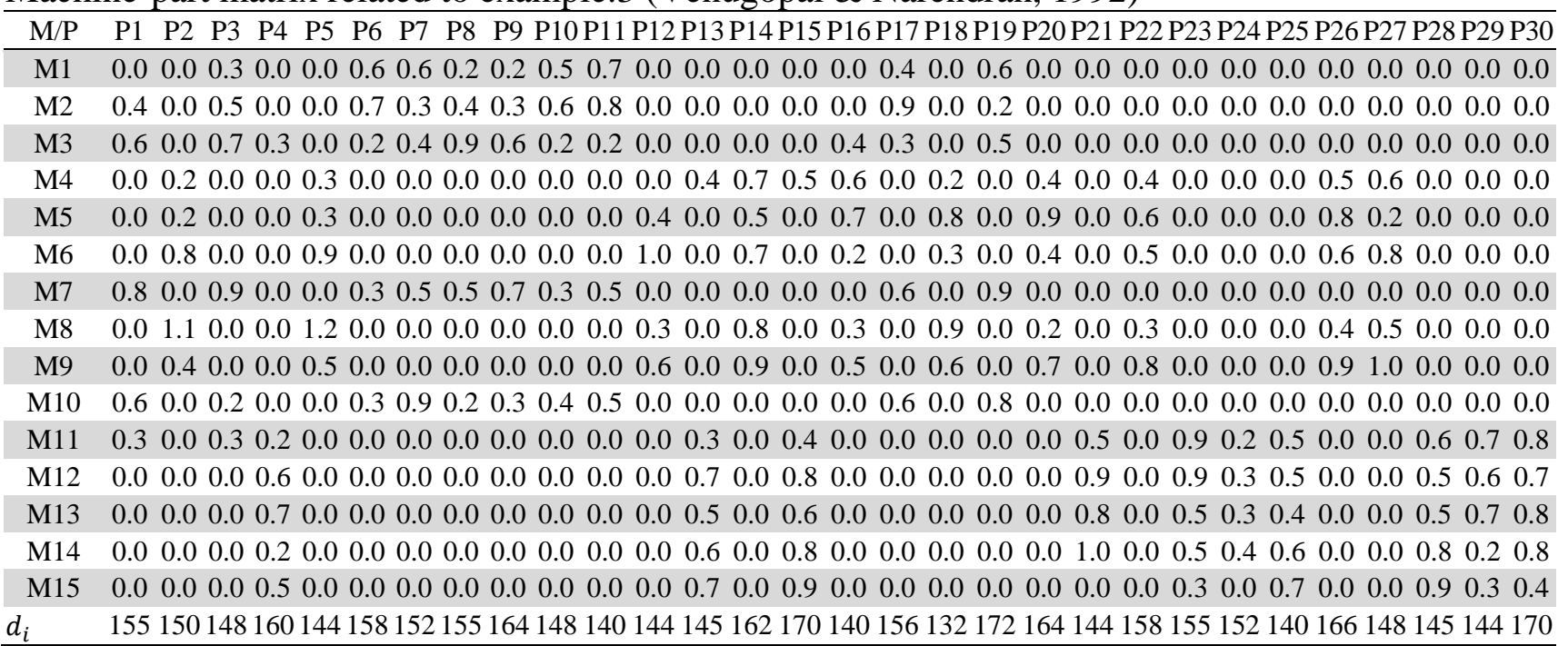


Table 8

Unit production and outsourcing costs (example 3)

\begin{tabular}{|c|c|c|c|c|c|c|c|c|}
\hline part & $\begin{array}{c}\text { Unit } \\
\text { production } \\
\text { cost } \\
\end{array}$ & $\begin{array}{c}\text { Unit } \\
\text { outsourcing } \\
\text { cost } \\
\end{array}$ & part & $\begin{array}{c}\text { Unit } \\
\text { production } \\
\text { cost } \\
\end{array}$ & $\begin{array}{c}\text { Unit } \\
\text { outsourcing } \\
\text { cost }\end{array}$ & part & $\begin{array}{c}\text { Unit } \\
\text { production } \\
\text { cost } \\
\end{array}$ & $\begin{array}{c}\text { Unit } \\
\text { outsourcing } \\
\text { cost } \\
\end{array}$ \\
\hline P1 & 8.2 & 13.9 & P11 & 11.3 & 16.8 & P21 & 11.1 & 16.6 \\
\hline P2 & 16.9 & 21.3 & P12 & 10.2 & 15.6 & P22 & 10.8 & 15.4 \\
\hline P3 & 9.7 & 13.7 & P13 & 15.2 & 22.0 & P23 & 19.6 & 24.1 \\
\hline P4 & 10.0 & 14.2 & P14 & 18.3 & 24.5 & P24 & 17.2 & 24.3 \\
\hline P5 & 8.7 & 14.1 & P15 & 12.1 & 20.0 & P25 & 19.8 & 27.6 \\
\hline P6 & 8.4 & 15.6 & P16 & 12.5 & 19.3 & P26 & 10.7 & 17.3 \\
\hline P7 & 19.9 & 24.6 & P17 & 15.2 & 19.6 & P27 & 8.7 & 14.8 \\
\hline P8 & 13.4 & 18.4 & P18 & 8.6 & 11.9 & P28 & 17.1 & 23.0 \\
\hline P9 & 14.0 & 20.0 & P19 & 12.4 & 18.8 & P29 & 17.7 & 25.1 \\
\hline P10 & 9.6 & 16.6 & $\mathrm{P} 20$ & 18.3 & 21.9 & P30 & 12.5 & 18.7 \\
\hline
\end{tabular}

Table 9

Capacity and purchase price of machines (example 3)

\begin{tabular}{cccccccc}
\hline Machine & $u_{k 1}$ & $u_{k 2}$ & $u_{k 3}$ & $c_{k 1}^{m}$ & $c_{k 2}^{m}$ & $c_{k 3}^{m}$ \\
\hline M1 & 92 & 111 & 125 & 207 & 231 & 469 & 508 \\
M2 & 131 & 147 & 160 & 429 & 486 & 519 & 559 \\
M3 & 115 & 127 & 150 & 405 & 441 & 462 \\
M4 & 102 & 126 & 153 & 411 & 441 & 469 \\
M5 & 122 & 139 & 163 & 494 & 532 & 557 \\
M6 & 221 & 246 & 267 & 201 & 229 & 253 \\
M7 & 109 & 123 & 142 & 253 & 289 & 320 \\
M8 & 222 & 238 & 255 & 397 & 420 & 452 \\
M9 & 230 & 253 & 280 & 187 & 227 & 267 \\
M10 & 205 & 218 & 232 & 451 & 474 & 494 \\
M11 & 224 & 236 & 250 & 369 & 404 & 430 \\
M13 & 137 & 153 & 169 & 177 & 212 & 235 \\
M14 & 107 & 129 & 146 & 332 & 354 & 378 \\
M15 & 189 & 203 & 229 & 199 & 233 & 253 \\
\hline
\end{tabular}

Example 3 was solved for ten cases by considering different values of maximum number of cells $(c)$, capacity of cells $\left(C a_{j}\right)$ and available budget $(B)$.The computational results were summarized in Table 10. In the first three cases, the model of $\mathrm{CMS}^{\mathrm{E}}$ was solved optimally but in the remaining cases the solver was interrupted due to insufficient physical memory, from the other side the model of $\mathrm{CMS}^{\mathrm{C}}$ was optimally solved for the first two cases and in the remaining cases the solver was interrupted either due to insufficient physical memory or due to time limit.

Table 10

Computational results of example. 3 considering different parameters

\begin{tabular}{|c|c|c|c|c|c|c|c|c|c|c|}
\hline \multirow[t]{2}{*}{ Case } & \multirow[t]{2}{*}{ B } & \multirow[t]{2}{*}{$\mathrm{c}$} & \multirow[t]{2}{*}{$\mathrm{Ca}_{\mathrm{j}}$} & \multicolumn{3}{|c|}{$\mathrm{CMS}^{\mathrm{E}}$} & \multicolumn{3}{|c|}{$\mathrm{CMS}^{\mathrm{C}}$} & \multirow{2}{*}{$\begin{array}{c}\mathrm{TC} \\
\text { Improvement } \\
\%\end{array}$} \\
\hline & & & & $\mathrm{TC}$ & CPU time (s) & Opt. gap\% & TC & CPU time (s) & $\begin{array}{l}\text { Opt. } \\
\text { gap\% }\end{array}$ & \\
\hline 1 & 10000 & 1 & 8 & -3781.83 & 0.3 & 0 & -3236.8 & 0.3 & 0 & $14.41 \%$ \\
\hline 2 & 10000 & 2 & 8 & -7128.59 & 830 & 0 & -5836.8 & 923 & 0 & $18.12 \%$ \\
\hline 3 & 10000 & 3 & 8 & -8992.13 & 10596 & 0 & -7948.6 & 10800* & $2.14 \%$ & $11.6 \%$ \\
\hline 4 & 15000 & 4 & 5 & -8855.93 & $8555^{* *}$ & $2.79 \%$ & -7389.2 & $3849 * *$ & $14.04 \%$ & $16.56 \%$ \\
\hline 5 & 15000 & 4 & 6 & -9650.42 & $3078 * *$ & $17.63 \%$ & -8184 & $3008 * *$ & $25.26 \%$ & $15.20 \%$ \\
\hline 6 & 15000 & 4 & 7 & -11456.44 & $3409 * *$ & $13.60 \%$ & -9710.4 & $4176^{* *}$ & $28.20 \%$ & $15.24 \%$ \\
\hline 7 & 12000 & 5 & 8 & -10168.50 & $4795 * *$ & $9.43 \%$ & -8549.2 & $4752 * *$ & $27.72 \%$ & $15.92 \%$ \\
\hline 8 & 14000 & 5 & 8 & -11565.49 & $3727 * *$ & $7.82 \%$ & -10095.2 & $5086 * *$ & $19.80 \%$ & $12.71 \%$ \\
\hline 9 & 16000 & 5 & 8 & -12612.45 & $4252 * *$ & $13.90 \%$ & -11186.7 & $9158 * *$ & $25.24 \%$ & $11.30 \%$ \\
\hline 10 & 18000 & 5 & 8 & -13880.59 & $2919 * *$ & $10.80 \%$ & -12155.6 & $3823^{* *}$ & $25.72 \%$ & $12.43 \%$ \\
\hline
\end{tabular}

* in this case the solver was interrupted after 10800 seconds (3 hours)

** in this case the solver was interrupted due to insufficient physical memory 
The results of CPU times and optimality gap percents revealed that unlike previous examples, the $\mathrm{CMS}^{\mathrm{C}}$ needs longer computational time to solve optimally. According to the last column of Table 10, the average improvement percent is up to14.35\%, therefore it is deduced that the proposed production system is efficient. Fig. 6 shows the objective values of each case of example 3 for both models.

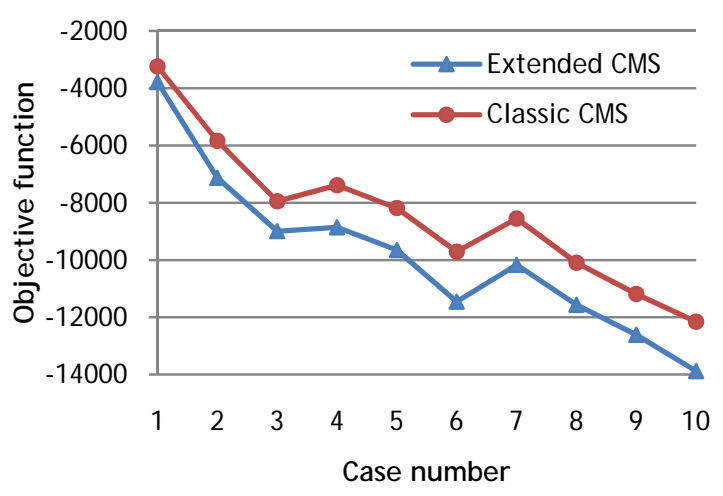

Fig. 6. Objective values of the $\mathrm{CMS}^{\mathrm{E}}$ and $\mathrm{CMS}^{\mathrm{C}}$ (example.3)

Also Table 11shows the formed cells and parts families in case 9 of example.3, (i.e. $B=18000$, $c=5$ and $\left.C a_{j}=8\right)$. In this case, 5 cells have been formed, where 9 parts are totally produced within the production system, 12 parts are simultaneously produced and outsourced and 9 parts are totally outsourced as the EEs.

\section{Table 11}

A sample solution of the $\mathrm{CMS}^{\mathrm{E}}$ (case 10, example.3)

\begin{tabular}{cll}
\hline $\begin{array}{c}\text { Cell } \\
\text { no. }\end{array}$ & Machines-type (number allocated) & Parts (production percent) \\
\hline 1 & $\begin{array}{l}\text { M1-2 (2), M2-3 (1), M3-3 (1), M7-1 (1), M7-3 (1), } \\
\text { M10-1 (1) }\end{array}$ & P8 (24.66\%), P10 (100\%), P19 (100\%) \\
& M1-2 (2), M2-1 (2), M3-3 (1), M7-3 (2), M10-1 (1), & P6 (100\%), P7 (7.55\%), P9 (89.23\%), P11 (92.91\%) \\
3 & $\begin{array}{l}\text { M4-3 (1), M11-3 (1), M12-1 (1), M12-3 (1), M13-3 } \\
\text { (2), M14-3 (1), M15-3 (1) }\end{array}$ & $\begin{array}{l}\text { P13 (100\%), P15 (7.93\%), P21 (10.18\%), P23 } \\
4\end{array}$ \\
$\begin{array}{l}\text { M11-2 (1), M12-3 (1), M13-1 (2), M14-3 (1), M15-1 } \\
\text { (2) P24 (100\%), P29 (100\%) }\end{array}$ & P25 (100\%), P28 (96.12\%), P30 (24.63\%) \\
5 & $\begin{array}{l}\text { M4-3 (1), M5-3 (1), M6-2 (1), M6-3 (1), M8-1 (2), } \\
\text { M9-2 (2) }\end{array}$ & $\begin{array}{l}\text { P2 (100\%), P5 (97.56\%), P12 (100\%), P26 (5.99\%), } \\
\text { P27 (85.45\%) }\end{array}$ \\
\hline
\end{tabular}

\section{Conclusions}

In this study, a new mathematical model in the CMS has been presented. It is assumed that the production quantity of each part is a decision variable and unsatisfied demand of parts would be outsourced to the external supplier. In addition, the EEs are totally outsourced.

The problem was formulated under budget, machines capacity and demand constraints to minimize variable cost. To compare the model with the traditional approach, three numerical examples with different parameters were solved. In the first example, we compared the $\mathrm{CMS}^{\mathrm{E}}$ and $\mathrm{CMS}^{\mathrm{C}}$ considering different available budgets and it was concluded that the extended model is better than or equal to the classical one in terms of the objective function, also in some cases the extended model performed better than the classical model both in the objective and remaining budget. The next example was solved with different cell capacity and it was concluded that the $\mathrm{CMS}^{\mathrm{E}}$ could obtain efficient solutions by using of unutilized machines. In the last example, we compared $\mathrm{CMS}^{\mathrm{E}}$ and $\mathrm{CMS}^{\mathrm{C}}$ considering different parameters, including available budget, maximum number of cells and capacity of cells. In this example, it was concluded that, unlike previous examples, the $\mathrm{CMS}^{\mathrm{C}}$ requires more computational time and physical memory to solve the problem, furthermore it was deduced that 
$\mathrm{CMS}^{\mathrm{E}}$ could obtain better solution up to $14.35 \%$ better than the CMS ${ }^{\mathrm{C}}$. Finally, it was concluded that considering the production volume of parts as a decision variable would increase the performance of the manufacturing system, considerably.

\section{References}

Akturk, M.S., \& Turkcan, A. (2000).Cellular manufacturing system design using a holonistic approach. International Journal of Production Research, 38(10), 2327-2347.

Arıkan, F., \& Güngör, Z. (2009). Modeling of a manufacturing cell design problem with fuzzy multiobjective parametric programming. Mathematical and Computer Modelling, 50, 407-420.

Car, Z., \& Mikac, T. (2006). Evolutionary approach for solving cell-formation problem in cell manufacturing. Advanced Engineering Informatics, 20, 227-232.

Chan, F.T.S., Lau, K.W., Chan, P.L.Y. and Choy, K.L. (2006). Two-stage approach for machine-part grouping and cell layout problems. Robotics and Computer-Integrated Manufacturing, 22, 217238.

Chiang, C.P. and Lee, S.D. (2004). Joint determination of machine cells and linear inter cell layout. Computers \& Operations Research, 31, 1603-1619.

Das, K., Lashkari, R.S., \& Sengupta, S. (2007). Machine reliability and preventive maintenance planning. European Journal of Operational Research, 183, 162-180.

Elbenani, B., \& Ferland, J.A. (2010).An exact method for solving the manufacturing cell formation problem. CIRRELT, 1-10.

Fallah-Alipour, K., \& Shamsi, R. (2008).A Mathematical Model for Cell Formation in CMS Using Sequence Data. Journal of Industrial and Systems Engineering, 2(2), 144-153.

Filho, E.V.G., \& Tiberti, A. J. (2006).A group genetic algorithm for the machine cell formation problem. International Journal of Production Economics, 102, 1-21.

Ghezavati, V.R., \& Saidi-Mehrabad, M. (2011). An efficient hybrid self-learning method for stochastic cellular manufacturing problem: A queuing-based analysis. Expert Systems with Applications, 38, 1326-1335.

Heragu, S.S., \& Chen, J.S. (1998). Optimal solution of cellular manufacturing system design: Benders' decomposition approach. European Journal of Operational Research, 107, 175-192.

Jeon, G., \& Leep, H.R. (2006). Forming part families by using genetic algorithm and designing machine cells under demand changes. Computers \& Operations Research, 33, 263-283.

Jolai, F., Tavakkoli-Moghaddam, R., Golmohammadi, A., \& Javadi, B. (2012).An Electromagnetismlike algorithm for cell formation and layout problem. Expert Systems with Applications, 39, 21722182.

Kia, R., Paydar, M. M., Alimardany Jondabeh, M., \& Javadian, N. (2011). A fuzzy linear programming approach to layout design of dynamic cellular manufacturing systems with route selection and cell reconfiguration. International Journal of Management Science and Engineering Management, 6(3), 219-230.

Kioon, S.A., Bulgak, A.A., \& Bektas, T. (2009). Integrated cellular manufacturing systems design with production planning and dynamic system reconfiguration. European Journal of Operational Research, 192, 414-428.

Panchalavarapu, P.R., \& Chankong, V. (2005).Design of cellular manufacturing systems with assembly considerations. Computers \& Industrial Engineering, 48, 449-469.

Saad, S.M. (2003). The reconfiguration issues in manufacturing systems. Journal of Materials Processing Technology, 138, 277-283.

Schaller J. (2007). Designing and redesigning cellular manufacturing systems to handle demand changes. Computers \& Industrial Engineering, 53, 478-490.

Singh, N. (1993). Design of cellular manufacturing systems: An invited review. European Journal of Operational Research, 69, 284-291. 
Sobhanallahi, M.A., Jahanshahloo, G.R., Amin, G.R., \& Shayan E. (2002). Threshold value for the number of cells in group technology. Computer \& Industrial Engineering, 42, 231-236.

Solimanpur, M., Vrat, P. and Shankar, R. (2004).A heuristic to minimize makespan of cell scheduling problem. International Journal of Production Economics, 88, 231-241.

Tavakkoli-Moghaddam, R., Javadian, N., Javadi, B., \& Safaei, N. (2007). Design of a facility layout problem in cellular manufacturing systems with stochastic demands. Applied Mathematics and Computation, 184, 721-728.

Tavakoli-Moghadam, R., Javadi, B., Jolai, F., \& Mirgorbani, S.M. (2006).An efficient algorithm to inter and intra-cell layout problems in cellular manufacturing systems with stochastic demands.IJE Transactions, 19(1), 67-78.

Teymourian, E., Mahdavi, I., \& Kayvanfar, V. (2011). A new cell formation model using sequence data and handling cost factors. Proceedings of the 2011 International Conference on Industrial Engineering and Operations Management, Kuala Lumpur, Malaysia, January 22-24.

Tsai, C.C., Chu, C.H. and Barta, T.A. (1997).Modeling and analysis of a manufacturing cell formation problem with fuzzy mixed-integer programming.IIE Transactions, 29, 533-547.

Venugopal, V. and Narendran, T.T. (1992).A genetic algorithm approach to the machine-component grouping problem with multiple objectives. Computers in Industrial Engineering, 22 (4), 469-480. 